\title{
Group foraging in a marine gastropod predator: benefits and costs to individuals
}

\author{
Kenneth M. Brown ${ }^{1}$, James E. Alexander $\mathrm{Jr}^{2}$ \\ ${ }^{1}$ Department of Zoology, Louisiana State University, Baton Rouge, Louisiana 70803, USA \\ ${ }^{2}$ Water Resources Laboratory, University of Louisville, Louisville, Kentucky 40292, USA
}

\begin{abstract}
We studied the benefits of group foraging for individuals in the marine gastropod Stramonita (=Thais) haemastoma, which preys on the oyster Crassostrea virginica along the coast of Louisiana, USA. From 40 to $58 \%$ of the snails at 2 sites on 2 dates were feeding with at least 1 additional snail, suggesting group feeding occurs frequently in the field. In the laboratory, we studied the feeding of solitary foragers as well as groups of 4 snails, and found that, for snails feeding in groups on both small ( $<70 \mathrm{~g}$ wet mass) and large oyster prey, per capita feeding rates actually decreased. However, the fraction of tissue removed per oyster was on average $21 \%$ greater for the snails feeding in groups, resulting in similar per capita oyster tissue consumption rates and growth rates for solitary and group foragers. Inter-feeding intervals also decreased for snails feeding in groups. Oyster-handling times were similar for snails feeding in groups and for solitary snails, indicating little benefit in subduing prey, but handling times did increase with prey size, suggesting large oysters may be more difficult to consume. Feeding rates and percent consumption were also lower for large oysters, and snails fed in larger groups when feeding on larger oyster prey. In the group feeding treatment, snails joined oysters already under attack much more frequently than they initiated an attack, joined with others to initiate an attack, or fed alone. These trends were also more pronounced for snails feeding on larger prey, and most snails pursued a mixed strategy, both initiating and joining oyster prey. Most additional foragers joined early in the foraging bout. We suggest several explanations for the existence of group foraging: not that it increases individual feeding rates, but that it occurs instead because (1) there is no measurable cost in rates of tissue consumption for individuals feeding in groups, (2) not all oyster tissue can be removed by solitary foragers, (3) there is no mechanism available for snails to defend a prey, and (4) it may provide a mechanism for handling larger oyster prey.
\end{abstract}

KEY WORDS: Group foraging $\cdot$ Stramonita $\cdot$ Crassostrea

\section{INTRODUCTION}

Animals may join groups to decrease predation risk and improve foraging efficiency (Alexander 1974, Wilson 1975, Bertram 1978, Pulliam \& Caraco 1984), or to steal food, increase chances of locating food, or increase the vulnerability of others to predators (Hamilton 1971, Ward \& Zahavi 1973, Bertram 1978, Bernard \& Sibly 1981). Packer \& Ruttan (1988) predicted that group foraging should occur only where prey were relatively large and difficult to handle, but also predicted that the frequency of 'cheating' (e.g. sharing in the rewards but not the cost of foraging) should increase in larger groups.

Although most empirical studies of group foraging have been on vertebrates (Packer \& Ruttan 1988), sev- eral taxa of invertebrates feed in groups as well. In some spiders, for example, group foraging may be advantageous (1) for efficiently handling large, hard to consume prey (termed the 'ephemeral' food resource hypothesis) that exceed the gut capacity of single spiders, (2) if the increased density of ultravioletreflecting webs spun by groups increases per capita prey capture rates, or (3) if prey 'ricochet' into a neighboring web while escaping (see review in Uetz 1992). Similarly, the flatworm Dugesia tigrina has greater feeding and reproductive rates when it feeds in groups (Cash et al. 1993).

In gastropods, group feeding is relatively unstudied, although it occurs in a herbivorous sea slug (Trowbridge 1991), but only on some algal food types, and 
only results in greater individual growth under certain conditions. In marine gastropods of the genus Thais, group feeding is usually not considered adaptive for individuals because of the small relative size of barnacle or mussel prey (Morgan 1972, Hughes \& Dunkin 1984). Aggregations of temperate zone whelks in crevices may instead serve to reduce desiccation, or lower mortality rates during winter storms (Feare 1971, Menge 1978, Fairweather et al. 1984, Moran 1985, Fairweather 1988a). Although not feeding in groups on individual barnacles, whelks still forage in aggregations, and dramatically reduce prey populations in local areas (Fairweather 1988a, b).

However, the southern oyster drill Stramonita (=Thais) haemastoma Grey has often been observed feeding in groups on individual oysters (reviewed in Butler 1985, also K. Brown pers. obs.). The southern oyster drill uses chemical cues to find its prey, including amino acids released by oysters (Smith 1983). Oyster drills attack bivalve prey at the shell margins, by repeated alteration of radular scraping and acid secretions from an accessory boring organ on the foot (Butler 1985, Brown \& Richardson 1987). When a large enough hole is created between the valves, the snail's proboscis is inserted, and a toxin and proteolytic enzymes are injected. Oyster tissue is then ingested through the proboscis until oyster adductor muscles tire, the oyster gapes, and any remaining tissue is lost (e.g. the solubilized tissue remnants drift away before they can be consumed, and the snail has no way of feeding on any remaining solid tissue).

In an earlier paper (Brown \& Richardson 1987), we noted that snails feeding in groups had greater total feeding rates and could take more difficult prey like large oysters, but did not explicitly address the mechanisms for these results. Group feeding might alter the foraging success of oyster drills in a number of ways. First, since oyster drills locate their prey by chemoreception, scents released by injured oysters, or feeding snails, might attract additional predators. If this were the case, we would predict snails feeding in groups to have shorter inter-feeding intervals, and that most additional snails would join late in the foraging bout, after the oyster's shell had been drilled, and scents produced. Second, groups of snails might be more likely to produce enough toxin to kill large oysters. If this were the case, we would expect handling times to decrease when snails fed in groups, especially for larger oyster prey. Third, snails feeding in groups might remove a greater portion of prey tissue before the oyster gaped, perhaps offsetting any costs associated with more predators sharing the prey. If this were the case, per capita prey tissue consumption rates and growth rates would not decline for group foragers.
In this paper, we recorded the frequency of group attacks by southern oyster drills on oysters at 2 sites along the coast of Louisiana, USA, where we had previously worked (Brown \& Richardson 1987), to determine if group feeding was common in nature. To test the hypotheses and predictions outlined above, we used laboratory experiments to compare solitary foragers versus snails feeding in a group to determine (1) any increase (or decrease) in per capita feeding rates (expressed both as number and dry mass of tissue consumed) and in snail growth rates, (2) any decrease in inter-feeding intervals in group predators, as well as the time course of attack by additional snails, (3) any changes in handling times for group predators, and (4) any increase in the fraction of tissue extracted per prey by group foragers. We also determined whether feeding group size increased with increasing oyster size, as expected if snails took advantage of increased tissue availability. Because oyster drills apparently cannot defend a prey, they might attempt instead to limit losses to additional snails by moving to another oyster prey. We looked for this response by assessing whether the initiator was more likely to 'give up' as each additional predator joined. For snails feeding in groups, we also recorded how frequently each snail initiated feeding bouts, jointly initiated a feeding bout, joined an oyster already under attack, or fed alone, as well as assessing intra-individual variation in feeding strategies.

\section{METHODS}

Study site and organisms. The northern Gulf of Mexico is a relatively sheltered marine environment with average tidal range of approximately $0.7 \mathrm{~m}$, silty sediments, and variable salinities (Britton \& Morton 1989). Oyster beds occur intertidally in this area, and oyster drills are frequently found subtidally on jetties and other man-made hard substrata. Besides oysters, oyster drills feed on barnacles, mussels and encrusting bryozoans (Butler 1985, Brown \& Richardson 1987). Stramonita haemastoma are active predators over a salinity range of 15 to $40 \%$ and 10 to $30^{\circ} \mathrm{C}$ (Stickle 1985), and reach densities as high as 40 ind. $\mathrm{m}^{-2}$ (Brown \& Richardson 1987).

Field observations. We observed snails feeding at 2 sites along the Louisiana coast to determine if group feeding occurred frequently in the field. Both sites were near the Port Fourchon Marine Laboratory of the Louisiana Universities Marine Consortium (LUMCON) and are described in more detail in Brown \& Richardson (1987) and Richardson \& Brown (1990). Snails and oysters were observed at low tide $(-0.3 \mathrm{~m} \mathrm{MLW})$ on 2 dates on concrete bridge pilings at Caminada Pass and once on a man-made jetty at Belle Pass. For approxi- 
mately $1 \mathrm{~h}$ on each date, we recorded the number of snails feeding on oysters. To determine if snails were actually feeding on the oysters, we pried oyster drills off; actively feeding snails required considerable force to remove them from the oysters, and only these individuals were recorded as predators. In many cases we also observed an extended proboscis, again indicating snails were feeding.

Laboratory feeding experiment. All snails used in experiments were collected in August 1991 (Block 1) or September 1991 (Block 2) from a jetty adjoining the marine laboratory. Snail size affects prey choice and feeding rate (Brown \& Richardson 1987), and only large Stramonita haemastoma (mean shell length \pm SE $=56.0 \pm 1.0 \mathrm{~mm}, \mathrm{~N}=80$ ) were therefore used in experiments, and each snail was starved for $1 \mathrm{wk}$ preceding experiments to standarize hunger levels. Oysters Crassostrea virginica Gmelin were hand collected from an intertidal oyster reef in a Spartina alterniflora marsh directly behind the LUMCON laboratory.

To ease logistic constraints, e.g. setting up experiments and making frequent behavioral observations, we chose a randomized block design with a 2 -way factorial arrangement ( 1 vs 4 snails, and small vs large oyster prey) of treatments. The first experimental block began on September 23, 1991 and continued for $3 \mathrm{wk}$, until October 14. The time interval of the block was chosen to allow repeated feeding of the snails, which, based on earlier data (Brown \& Richardson 1987), were predicted to consume on average an oyster every 1 to $2 \mathrm{~d}$. Although handling times were somewhat longer in this study ( 50 to $100 \mathrm{~h}$, see 'Results'), a 3 wk interval still allowed from 3 to 16 oysters to be consumed per trial, depending on the treatment and block. The second block ran from October 21 to November 14, 1991.

Each block had 16 aquaria, randomly assigned so that 4 replicate aquaria were allocated to each of 4 treatments: 1 or 4 snail predators, and small $(<70 \mathrm{~g}$ total wet mass, mean $\pm \mathrm{SE}=36.997 \pm 1.536 \mathrm{~g}$ ) or large ( $>70 \mathrm{~g}$, mean $\pm \mathrm{SE}=142.899 \pm 6.924 \mathrm{~g})$ oyster prey. A density of 1 or 4 snails per 381 aquarium (equivalent to about 8 to 30 snails $\mathrm{m}^{-2}$ ) was chosen to be roughly similar to field densities (Brown \& Richardson 1987), to help minimize any laboratory biases towards increased chances of prey encounter. Two oyster size classes were used to determine if the success of snails feeding in groups was greater for larger prey, e.g. by producing more toxin. Oyster size classes were chosen because $70 \mathrm{~g}$ wet total mass was the median size of oysters in the reef from which the prey were taken (K. Brown unpubl. data). Four oysters were placed in each aquarium, and were replenished with similarly sized prey as oysters were consumed. This oyster density is also well within the range found in the oyster reef (150 to $240 \mathrm{~m}^{-2}$; K. Brown unpubl. data).
Experimental units were $38 \mathrm{l}$ aquaria with undergravel $(3 \mathrm{~cm}$ of chipped oyster shell) filters and 20 to $25 \%$ artificial seawater maintained at 23 to $26^{\circ} \mathrm{C}$, and kept on a $12 \mathrm{~h}$ light:12 h dark cycle, all chosen to represent summer conditions when feeding rates are maximal (Brown \& Richardson 1987). At 3 times during each daylight period, and once during the night, approximately every $6 \mathrm{~h}$, each aquarium was observed and the positions of all snails (on or near what oyster) were noted. All snails and oysters were marked with correction fluid and indelible ink to facilitate observations. Notes were also taken on whether oysters were feeding (valves relaxed) versus clamped. Oysters were considered dead when snails had ceased feeding and oysters would not clamp their valves when stimulated with a probe. Dead oysters which had no observations with predators were assumed to be natural deaths, and occurred only infrequently.

For each oyster eaten, we recorded (1) the total handling time, (2) the total dry oyster tissue consumed, (3) the estimated tissue consumed by each snail in the group feeding on the oyster, and (4) the percentage of the oyster tissue consumed. These variables were estimated as follows. (1) Total handling time per oyster was defined as the period during which at least 1 snail was feeding on the oyster plus one-half of the interval preceding the first observation with a predator and one-half of the time period after the last observation where the oyster was alive (Brown \& Richardson 1987). (2) Estimated dry tissue mass consumed per oyster was calculated from a regression of dry tissue mass (after drying for $24 \mathrm{~h}$ at $60^{\circ} \mathrm{C}$ in an oven) against initial wet total mass (shell + tissue + internal water) in 50 additional oysters collected at the same time as the oysters that were used as prey (oyster dry tissue mass in $\mathrm{mg}=0.218+0.009 \times$ initial wet mass, $\mathrm{r}=0.88$ ). (3) The amount of tissue consumed per snail was estimated by multiplying the estimated total prey dry mass (as calculated above) by that snail's fraction of the total number of hours that all snails spent feeding on the oyster. For example, if an oyster was killed after $30 \mathrm{~h}$ by 3 snails that spent 30,15 and $10 \mathrm{~h}$ feeding, then we assumed that each snail, respectively, consumed $30 / 55$, $15 / 55$ and $10 / 55$ of the estimated dry mass of the oyster. This method assumed that tissue extraction rates were constant over the foraging bout (e.g. that snails joining late for example have no advantage over initiators). Although we had no way of assessing such time-dependent effects, we consider our method conservative, since joiners could either benefit (if they did not need to spend as much energy drilling a prey) or be penalized (if they did not have enough time to completely drill through the shell). We thus analyzed data by averaging over all snails in a tank, so that variation in food intake between individuals was not analyzed. 
(4) Estimated oyster dry masses consumed were corrected by subtracting the dry mass of any tissue left in the oyster, after snails completed feeding, from estimated prey dry mass. The percentage of tissue removed was also calculated with these data [e.g. (estimated dry mass - tissue left mass)/estimated dry mass].

For each replicate experimental unit, we determined the (1) per capita feeding rate (averaged over the 4 snails in the group treatment), (2) average percentage of tissue consumed per oyster, (3) per capita tissue consumption (again averaged over all 4 snails), (4) average oyster handling time, (5) average inter-feeding interval (e.g. number of hours between feeding bouts), and (6) average feeding group size (for group snail treatments). For each snail, we also recorded the increment in wet mass over the experiment. These were the dependent variables used in the analysis of variance. All treatment variances were examined for heteroscedacity or mean-variance correlations (PROC UNIVARIATE; SAS 1985), and percentage prey consumption values were arcsine square-root transformed, and because of a mean-variance correlation, handling time data were log-transformed before analysis of variance (Sokal \& Rohlf 1981). Statistical analyses were completed on SAS (SAS 1985), and F-values are reported for the block, main, and interaction effects on each dependent variable, along with associated probability levels. The blocked design assumes no interactions between blocks and treatments.

For each snail, we recorded the number of times it initiated a predator-prey encounter, attacked concurrently with another snail, joined an attack already under way, or fed alone. A G-test of independence, using a 2 by 4 contingency table, was performed to see if behavioral frequencies were independent of prey size (Sokal \& Rohlf 1981).

We also compared the frequency of initiation of attacks and that of joining to expected frequencies for both prey size categories. We calculated expected frequencies by noting, over all replicate tanks and observations, the proportion of oysters under attack. For example, if 1 out of 4 oysters was already under attack, on the average, we would expect snails to pick unattacked oysters $75 \%$ of the time. In this analysis, we also looked for heterogeneity of prey selection among snails assigned to a given group-feeding treatment using a replicated goodness-of-fit $G$-test (Sokal \& Rohlf 1981). This analysis provides a $G_{H}$ (heterogeneity) statistic that tests whether frequencies are homogeneous among individuals, and $G_{p}$ (pooled) statistic that tests whether the pooled data fit the null hypothesis (i.e. snails are choosing oysters already under attack solely on their relative frequency). By comparing the relative magnitude of the $G_{H}$ and $G_{P}$ statistics, the degree of intra-individual variation in feeding strategies can be gauged, that is, whether snails show a mixed strategy as opposed to only initiating attacks or joining prey already under attack.

To determine if snails initiating a feeding bout were more likely to quit feeding when others joined, we regressed the proportion (arcsine square-root transformed) of the total handling time that the initiator remained against the number of snails joining. While our main emphasis was on long-term differences in feeding rates between treatments, we were also interested in the time sequence of joint attacks. For example, if injured oysters release scents to attract predators, then more snails should, on the average, attack later in the foraging bout. To test this idea, we split each handling time into 10 equal segments and noted when additional snails joined. A G-test was performed for each prey size to test the null hypothesis that $1 / 10$ of the additional attacks should occur in each segment.

\section{RESULTS}

\section{Field observations}

Although solitary foragers were the most frequent category at each of the sites, a considerable number of snails still fed in groups (Table 1). For example, at Caminada Pass in July 1989, $50 \%$ of the foraging snails were feeding with at least 1 additional snail. At Caminada Pass in September 1991, 57.9\% of the snails were observed feeding in groups. Finally, in September 1991 at Belle Pass, $40.6 \%$ of the snails were feeding in groups.

\section{Laboratory experiment}

The number of oysters consumed per snail declined (Fig. 1) either when snails fed in groups $(F=15.1$, $p=0.006)$, or when snails fed on large oysters $(F=41.9$, $\mathrm{p}<0.0001)$. However, there was not a significant inter-

Table 1. Number of Stramonita haemastoma observed feeding in groups of various sizes on Crassostrea virginica at 2 sites along the Louisiana, USA, coast on 2 dates

\begin{tabular}{|c|c|c|c|c|c|c|}
\hline \multirow[t]{2}{*}{ Site } & \multicolumn{6}{|c|}{ No. of snails feeding in groups of: } \\
\hline & 1 & 2 & 3 & 4 & 5 & $6+$ \\
\hline \multicolumn{7}{|l|}{ July 27, 1989} \\
\hline Caminada Pass & 46 & 20 & 9 & 0 & 5 & 12 \\
\hline \multicolumn{7}{|c|}{ September 14, 1991} \\
\hline Caminada Pass & 16 & 6 & 6 & 0 & 10 & 0 \\
\hline Belle Pass & 19 & 6 & 3 & 4 & 0 & 0 \\
\hline
\end{tabular}




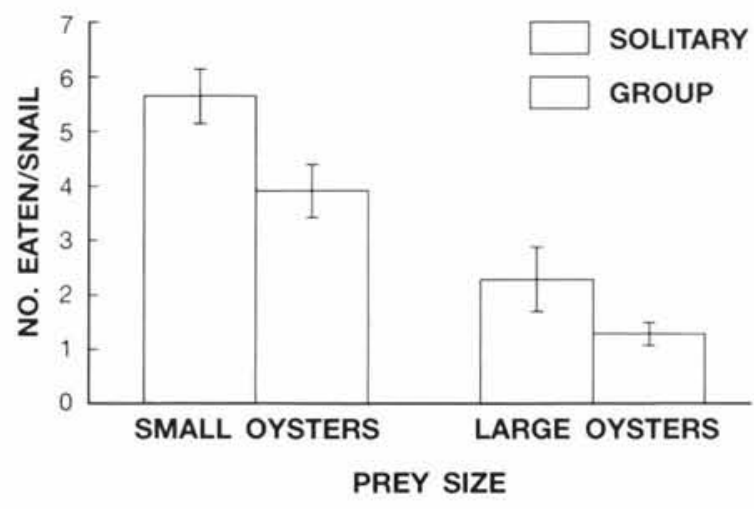

Fig. 1. Stramonita haemastoma and Crassostrea virginica. Average per capita prey consumption $( \pm \mathrm{SE}, \mathrm{N}=8$ replicate tanks) for snails feeding alone, or in groups of 4 , on 2 oyster size classes

action effect between foraging mode and prey size $(F=0.7, \mathrm{p}=0.43)$, nor was there a significant block effect $(F=1.8, \mathrm{p}=0.19)$. Averaged over both prey sizes, feeding rates declined by $35 \%$ for snails feeding in groups, while averaged over both feeding modes, feeding rates on large oysters were only $37 \%$ of those on small oysters.

Snails did, however, remove a greater fraction of oyster tissue (Fig. 2A, $82 \%$ ) when feeding in groups
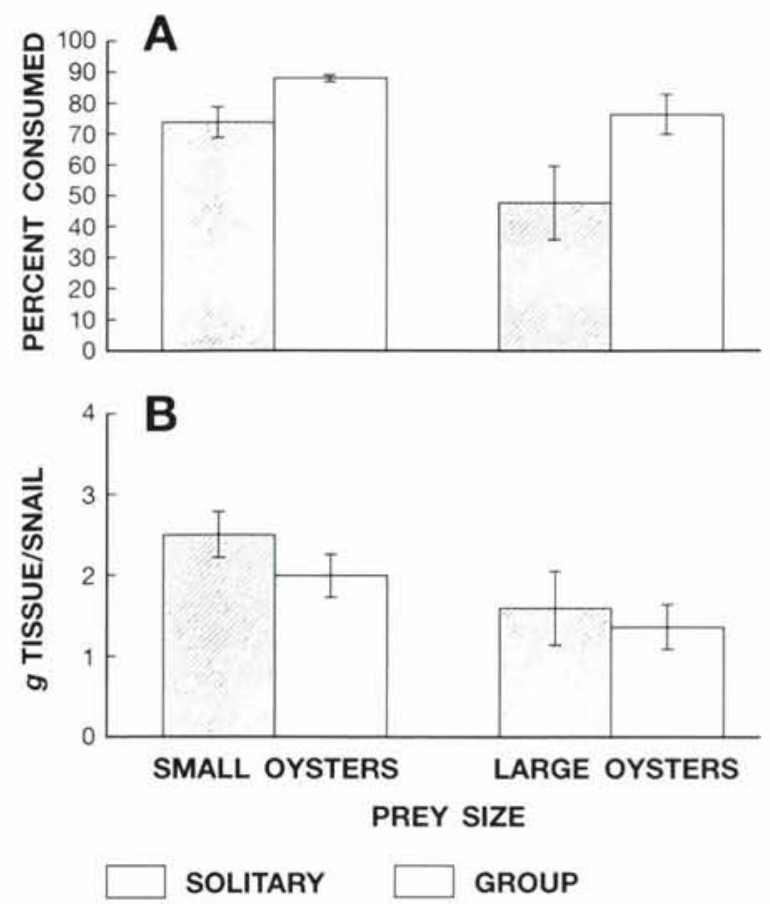

Fig. 2. Stramonita haemastoma and Crassostrea virginica. (A) Average percentage of tissue consumed per oyster, and (B) average per capita dry tissue weight of oyster consumed, for snails feeding alone, or in groups of 4 , on 2 oyster size classes ( $\pm \mathrm{SE}, \mathrm{N}=8$ replicate tanks) than when feeding alone $(61 \%, F=5.3, \mathrm{p}=0.03)$. Oyster size did not have a significant effect on the percentage of tissue removed $(F=3.5, \mathrm{p}=0.07)$, nor were the interaction $(p=0.49)$ or block effects significant $(p=0.75)$. Perhaps because snails were able to remove a greater fraction of the oyster's tissue when feeding in groups, per capita tissue consumption did not differ between feeding modes (Fig. 2B, $F=1.3, p=0.26$ ). However, per capita tissue consumption did decrease by $45 \%$ for snails feeding on larger oysters $(F=5.7, \mathrm{p}=0.002)$. In this case as well, neither the block $(p=0.16)$ nor the interaction between size and feeding mode $(p=0.67)$ were significant.

Percentage increase in wet tissue weight was greatest in the solitary snails feeding on small oysters (Fig. 3), followed by snails feeding in groups on small oysters, feeding in groups on large prey, and finally, solitary snails feeding on large oysters had the smallest growth rates. A 1-way analysis of covariance indicated that neither of the treatments $(F=1.8, \mathrm{p}=0.15)$ nor initial size (the covariate, $F=2.7, \mathrm{p}=0.10$ ) had significant effects on percentage growth.

Although mean handling times were greater for groups of snails on each prey size, the group effect was not significant in the analysis of variance (Fig. $4 \mathrm{~A}, F=$ $2.4, p=0.13)$. However, there was a size-dependent increase in handling time $(F=9.6, \mathrm{p}=0.005)$. Regression of handling times against oyster mass and, for the group feeding treatment, number of snails feeding did however indicate both of these factors were important (Table 2). For single snails, oyster weight explained a significant proportion of variation in handling time. For snails feeding in groups, oyster weight again explained a significant portion of the variation, and adding the second variable, number of snails feeding, in a multiple linear regression, further increased the proportion of the variation explained. Handling time

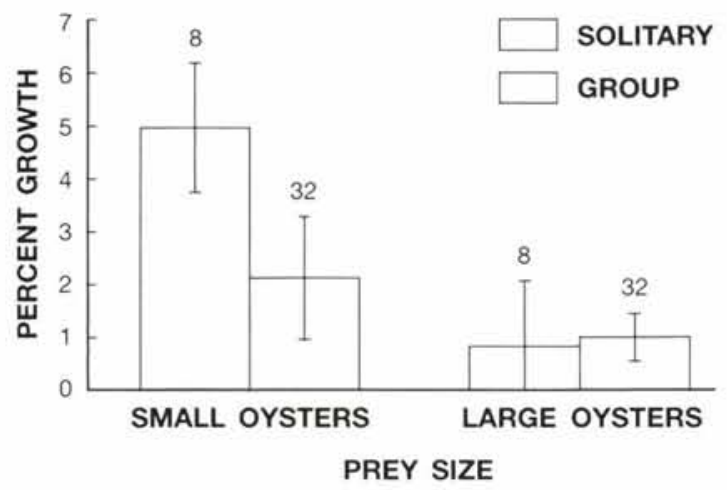

Fig. 3. Stramonita haemastoma and Crassostrea virginica. Average increase in wet weight per snail $( \pm \mathrm{SE}, \mathrm{N}$ given over each histogram) for snails feeding alone, or in groups of 4 , on 2 oyster size classes 

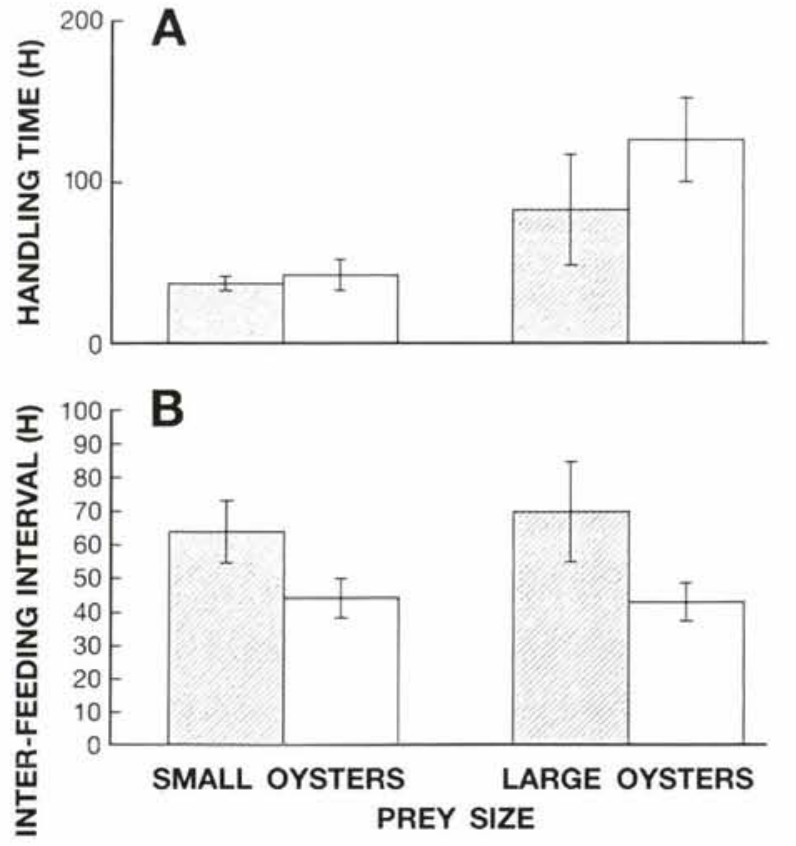

SOLITARY

GROUP

Fig. 4. Stramonita haemastoma and Crassostrea virginica. (A) Average oyster-handling times, and (B) average interfeeding intervals, for snails feeding alone, or in groups of 4 , on 2 oyster size classes $( \pm \mathrm{SE}, \mathrm{N}=8$ replicate tanks)

was positively related to the number of snails feeding (Table 2). Brown \& Richardson (1987) found no effect of drill feeding-group size on oyster-handling time, but did find a significant size-dependent increase. The average number of snails feeding in a group also increased from 2.0 to 2.7 when prey size increased $(t=4.7, \mathrm{p}<0.001)$.

Average inter-feeding intervals declined by $35 \%$ when snails fed in groups (Fig. $4 \mathrm{~B}, F=6.2, \mathrm{p}=0.02$ ). Prey size did not affect inter-feeding interval $(F=0.1$, $p=0.75)$, nor was the block $(p=0.41)$ nor interaction $(p=0.61)$ effect significant.

For both small and large oyster prey, snails clearly joined oysters already under attack more frequently than they initiated attacks, jointly initiated attacks, or fed alone (Fig. 5). Also, these trends were even more obvious for snails feeding on larger oysters than for

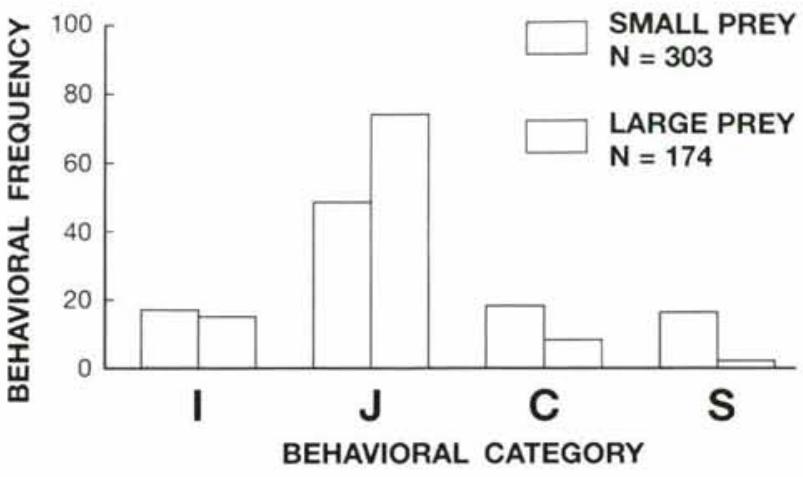

Fig. 5. Stramonita haemastoma and Crassostrea virginica. Relative frequencies of feeding behaviors for snails feeding in groups on small or large oyster prey. Data were collected from 32 snails in each oyster size category, and sample sizes refer to the total number of behaviors recorded for each prey size category. See text for statistical analyses. I: initiated feeding bout; $\mathrm{J}$ : joined an oyster already being attacked; $\mathrm{C}$ : concurrent initiation of an attack; S: solitary feeder

those feeding on small oysters ( $G$-test of independence $=12.8, \mathrm{p}<0.001$ ). Snails joined oysters already under attack roughly two-thirds of the time (small oysters) or three-quarters of the time (large prey) even though about two-thirds of the oysters in the tank were free of other predators (Table 3). Thus the pooled G-test was highly significant for both prey types. For small oyster prey, $G_{H}$ was also significant, although comprising only $15 \%$ of the total G. Most snails ( $91 \%$ ) had a mixed strategy when feeding on small oysters, and only $9 \%$ were specialists, only joining oysters already under attack. For the snails pursuing a mixed strategy, $23 \%$ (8) initiated attacks at least half of the time. For large oyster prey, $G_{\mathrm{H}}$ was also significant, but comprised only $8 \%$ of the total G. Twelve snails $(38 \%)$ only joined oysters under attack, and the rest pursued a mixed strategy. In this case, only 1 of the snails pursuing a mixed strategy initiated attacks more than $50 \%$ of the time. Taken together, these results again suggest a strong preference for oysters already under attack, and pursuit of a mixed strategy by most snails.

For both prey sizes, snails did not join oysters under attack randomly through time (Fig. 6). However, contrary to our expectiations, positive deviations occurred

Table 2. Stramonita haemastoma and Crassostrea virginica. Simple and multiple linear regression equations relating oysterhandling times (HT, in h) in hours to oyster wet mass (OM, in g) and to number of snails cooperating (NS) in group feeding treatments. $\mathrm{R}^{2}$ : proportion of variation in HT explained by the model. F-statistic refers to the significance of the $\mathrm{R}^{2}$ statistic

\begin{tabular}{|lllrl|}
\hline Feeding category & Equation & $\mathrm{R}^{2}$ & $F$ & $\mathrm{p}$ \\
\hline Single snails & $\mathrm{HT}=9.5+0.6 \mathrm{OM}$ & 0.23 & 17.5 & $<0.0001$ \\
Group snails & $\mathrm{HT}=16.1+0.6 \mathrm{OM}$ & 0.16 & 29.5 & $<0.0001$ \\
& $\mathrm{HT}=-26.7+0.4 \mathrm{OM}+23.9 \mathrm{NS}$ & 0.27 & 28.7 & $<0.0001$ \\
\hline
\end{tabular}


Table 3. Stramonita haemastoma and Crassostrea virginica. Frequencies observed and expected for snails initiating or joining an attack on an oyster (see text for how expected frequencies were generated). Pooled $G$-tests are for the hypothesis of no preference between either strategy, while the heterogeneity $G$ measures the degree of differences of strategies among individuals. $\cdots p<0.01$

\begin{tabular}{|c|c|c|c|c|c|c|}
\hline Treatment & Behavior & $\%$ Observed & $\%$ Expected & Tests & df & $G$ \\
\hline Small oysters & $\begin{array}{l}\text { Initiating } \\
\text { Joining }\end{array}$ & $\begin{array}{l}35 \\
65\end{array}$ & $\begin{array}{l}66 \\
34\end{array}$ & $\begin{array}{l}\text { Pooled } \\
\text { Heterogeneity } \\
\text { Total }\end{array}$ & $\begin{array}{r}1 \\
25 \\
26\end{array}$ & $\begin{array}{r}1118.2 \% \\
198.8 \% \\
1317.0^{*}\end{array}$ \\
\hline Large oysters & $\begin{array}{l}\text { Initiating } \\
\text { Joining }\end{array}$ & $\begin{array}{l}26 \\
74\end{array}$ & $\begin{array}{l}63 \\
37\end{array}$ & $\begin{array}{l}\text { Pooled } \\
\text { Heterogeneity } \\
\text { Total }\end{array}$ & $\begin{array}{r}1 \\
15 \\
16\end{array}$ & $\begin{array}{r}924.1^{*} \\
75.6 \\
999.7^{*}\end{array}$ \\
\hline
\end{tabular}

mostly in the earliest portion of the foraging bout, suggesting snails were attracted early to prey, not late in the bout when tissue might be leaking. The initiating snail was again not included in these data, so initial frequencies are not biased by that effect.

Finally, the tenacity of the first snail attacking an oyster did not appear dependent on the number of snails eventually joining the prey, since there was not a significant relationship between the percentage of the total handling time contributed by the initiator and the number of snails joining the group, for either small $\left(R^{2}=0.01\right.$, $\mathrm{p}=0.51)$ or large $\left(\mathrm{R}^{2}=0.05, \mathrm{p}=0.24\right)$ oyster prey.
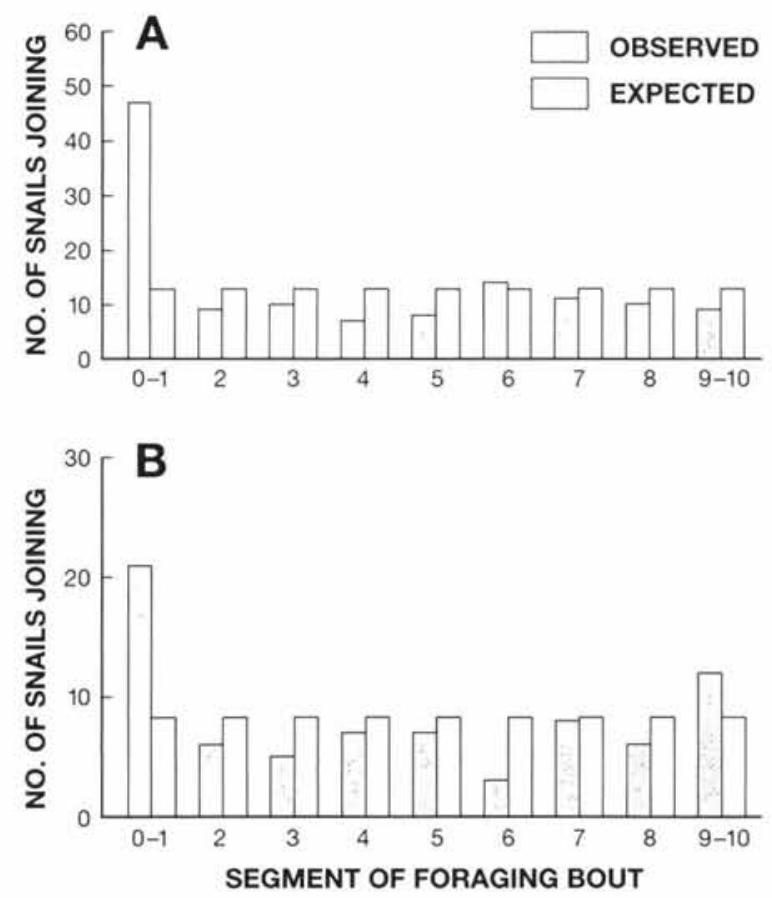

Fig. 6. Stramonita haemastoma and Crassostrea virginica. Temporal distribution of attacks observed by additional snails on (A) small and (B) large oysters already under attack, subdivided into tenths of the total handling time. Expected frequencies are based on the assumption that $10 \%$ of the snails should join in each interval

\section{DISCUSSION}

Stramonita haemastoma did feed in groups in the field, as 40 to $60 \%$ of individuals were observed feeding with at least 1 additional snail. While we did not record the number of oysters not under attack, many were observed, suggesting that joint attacks were not occurring because prey were limited. Additionally, group attacks by drills in the field have also been reported in the literature (Butler 1985). Given the observation that at least some drills feed in groups, an interesting question is why group foraging occurs in this snail, but seldom in other temperate whelks like Thais lapillus.

A number of factors may explain why Stramonita haemastoma feeds in groups on oysters. First of all, snails may have been able to detect scents from injured oysters, or from conspecific feeding. Although most additional snails joined early in the bout, the fact that inter-feeding intervals decreased still may suggest group feeding in some way facilitated prey location, perhaps because these chemosensory predators were attracted to leaking prey tissue (Smith 1983). Although the peak in recruitment was within the first tenth of the foraging bout, perhaps enough tissues leak by this time from the oyster to attract additional snails. Of course, these experiments were done in small aquaria where chemosensory cues would be easy to detect. The presence of at least some group feeding in the field, however, suggests such chemosensory cues could also operate on a larger scale. The Eastern oyster drill Urosalpinx cinera can for example detect peptides released by barnacle prey, which interestingly can be masked by oyster odors (Pratt 1974, Rittschof et al. 1983, Williams et al. 1983). U. cinera, however, can also learn to respond to oyster odor after feeding on oysters (Wood 1968). An alternative hypothesis could be, however, that these snails are in some way choosing to join groups early in the foraging bout, or are feeding more frequently simply to conserve the total amount of tissue ingested, since they are now sharing prey with groups of snails. 
Increased tissue removal before oysters gaped may also counteract sharing the tissue with additional predators, since per capita tissue consumption rates did not decrease in groups. Unlike in Thais lapilus, the relatively large size ratio of oysters to oyster drills (an average snail weighs about $50 \mathrm{~g}$ total wet weight while large oysters can reach 200 to $300 \mathrm{~g}$ ) allows groups to remove tissue which would not be accessible to a solitary snail forager. Corroborating this idea, group size increased for snails feeding on large oysters, which were more difficult to consume (e.g. were eaten less frequently, had more tissue wasted and greater handling times).

Interestingly, we could not detect any decrease in handling times when snails fed in groups. Evidently several snails injecting toxin into oysters were not able to kill the prey any more rapidly. This may mean most effort in subduing the oyster is expended by the first snail, and additional snails receive increased benefits. However, in a preliminary experiment, multiple drill holes were usually observed on oyster shells consumed by groups (J. E. Alexander pers. obs.), suggesting most snails attempt to drill a hole. Late-arriving snails might thus either receive fewer rewards (if they did not have time to drill a hole before the oyster gaped) or receive greater rewards (if they somehow could feed on leaking tissue but not have to exert all of the effort that the initial snails did). Morula marginalba, for example, attacks large limpets in groups, but only after the limpet has been weakened, at considerable expense, by the first snail (P. Fairweather pers. comm.). Similary, Nucella lapilus will feed on large mussels in groups in the laboratory (Hughes \& Dunkin 1984). We still consider our results to be conservative, however, in that they suggest average feeding rates did not increase when oyster drills foraged in groups, and there was no cost in terms of reduced growth rates.

From the opposite perspective, there is apparently little that a snail can do to dissuade additional conspecific predators. The drawn-out foraging behavior of the snails (e.g. secretion of acids, radular scraping, and secretion of toxin) does not appear compatible with actively patrolling the margin of the prey, and we saw no evidence of aggressive behavior exhibited by the initiating snails towards additional snails joining an oyster kill. Such behavioral interactions could also mitigate against group foraging (Ranta et al. 1993). Nor were snails that initiated a foraging bout more likely to leave as more snails joined, further supporting the idea that there is little cost of additional predators to the initial snail forager.

Our results thus suggest that group feeding in this marine predator does not lower handling time nor increase per capita feeding rates, but could be beneficial for feeding on large oyster prey, since considerable tissue is lost to single foragers on these prey.
Acknowledgements. We thank Sanford Roy, Stephanie Hancock, Libby Lancaster, Dave Swearingen, and Mike Conrad for help with the laboratory experiments. Elizabeth Li helped with the statistical analyses. Angela Stam, Loan Ly and Sabrina Guidry typed several versions of the manuscript.

\section{LITERATURE CITED}

Alexander, R. D. (1974). The evolution of social behavior. A. Rev. Ecol. Syst. 5: 325-383

Bernard, C. J., Sibly, R. M. (1981). Producers and scroungers: a general model and its application to captive flocks of house sparrows. Anim. Behav, 29: 543-550

Bertram, B. C. R. (1978). Living in groups: predators and prey, In: Krebs, J. R., Davies, N. B. (eds.) Behavioural ecology: an evolutionary approach, Chap. 3. Sinauer Associates, Inc, Sunderland, MA, p. 64-96

Britton, J. C., Morton, B. (1989). Shore ecology of the Gulf of Mexico. University of Texas Press, Austin

Brown, K. M., Richardson, T. D. (1987). Foraging ecology of the southern oyster drill Thais haemastoma (Grey): constraints on prey choice. J. exp. mar. Biol. Ecol. 114: 123-141

Butler, P. A. (1985). Synoptic review of the literature on the southern oyster drill Thais haemastoma floridana. NOAA tech. Rep. natn. Mar. Fish. Serv. 35

Cash, K. J., McKee, M. H., Wrona, F. J. (1993). Short- and long-term consequences of grouping and group foraging in the free-living flatworm Dugesia tigrina. J. Anim. Ecol. 62: 529-536

Fairweather, P. G. (1988a). Predation creates haloes of bare space among prey on rocky seashores in New South Wales. Austr. J. Ecol. 13: 401-409

Fairweather, P. G. (1988b). Correlations of predatory whelks with intertidal prey at several scales of space and time. Mar. Ecol. Prog. Ser. 45: 237-243

Fairweather, P. G., Underwood, A. J., Moran, M. J. (1984). Preliminary investigations of predation by the whelk Morula marginalba. Mar. Ecol. Prog. Ser. 17: 143-156

Feare, C. J. (1971). The adaptive significance of aggregation behaviour in the dogwhelk Nucella lapillus (L.). Oecologia 7: $117-126$

Hamilton, W. D. (1971). Geometry of the selfish herd. J. theor. Biol. 31: 295-311

Hughes, R. N., Dunkin, S. de B. (1984). Behavioural components of prey selection by dogwhelks, Nucella lapillus (L.). feeding on mussels, Mytilus edulis L., in the laboratory. J. exp. mar. Biol, Ecol. 77: 45-68

Menge, B. A. (1978). Predation intensity in a rocky intertidal community: relation between foraging activity and environmental harshness. Oecologia 34: 1-16

Moran, M. J. (1985). The timing and significance of sheltering and foraging behaviour of the predatory intertidal gastropod Morula marginalba Blainville (Muricidae). J. exp. mar. Biol. Ecol. 93: 103-114

Morgan, P. R. (1972). Nucella lapillus (L.) as a predator of edible cockles. J. exp. mar. Biol. Ecol. 8: 45-52

Packer, C., Ruttan, L. (1988). The evolution of cooperative hunting. Am. Nat. 132: 159-198

Pratt, D. M. (1974). Attraction to prey and stimulus to attack in the predatory gastropod Urosalpinx cinera. Mar. Biol. 27 : $37-45$

Pulliam, H. R., Caraco, T. (1984). Living in groups: is there an optimal group size? In: Krebs, J. R., Davies, N. B. (eds.) Behavioural ecology: an evolutionary approach, Chap. 5 . 2nd edn. Blackwell Scientific Publications, Oxford, p. $122-147$ 
Ranta, E., Rita, H., Lindstrom, K. (1993). Competition versus cooperation: success of individuals foraging alone and in groups. Am. Nat. 142: 42-58

Richardson, T. D., Brown, K. M. (1990). Wave exposure and prey size selection in an intertidal predator. J. exp. mar. Biol. Ecol. 142: 105-120

Rittschof, D., Williams, L. G., Brown, B., Carriker, M. R. (1983). Chemical attraction of newly hatched oyster drills. Biol. Bull. 164: 493-505

SAS (1985). SAS users guide: statistics, version 5. SAS, Inc., Cary, NC

Smith, D. J. (1983). Chemoattraction of the southern oyster drill Thais haemastoma towards the oyster Crassostrea virginica as a function of temperature and salinity. M.Sc. thesis, Louisiana State University, Baton Rouge

Sokal, R. R., Rolhf, F. J. (1981). Biometry. W. H. Freeman Co., San Francisco

Stickle, W. B. (1985). Effects of environmental factor gradients on scope for growth in several species of carnivorous marine invertebrates. In: Gray, J. S., Cristianson, M. E.

This article was presented by $R$. N. Hughes (Senior Editorial Advisor), Bangor, UK (eds.) Marine biology of polar regions and effects of stress on marine organisms. J. Wiley and Sons, London, p. 601-616

Trowbridge, C. D. (1991). Group membership facilities feeding of the herbivorous sea slug Placida dendritica. Ecology 72: $2193-2203$

Uetz, G. W. (1992). Foraging strategies of spiders. Trends Ecol. Evol. 7: 155-159

Ward, P., Zahavi, A. (1973). The importance of certain assemblages of birds as 'information-centers' for food finding. Ibis 115: 517-534

Williams, L. G., Rittschof, D., Brown, B., Carriker, M. R. (1983). Chemotaxis of oyster drills Urosalpinx cinera to competing prey odors. Biol. Bull. 164: 536-548

Wilson, E. O. (1975). Sociobiology: the new synthesis. Harvard University Press, Cambridge, MA

Wood, L. (1968). Physiological and ecological aspects of prey selection by the marine gastropod Urosalpinx cinera (Prosobranchia: Muricidae). Malacologia 6: 267-320

Manuscript first received: February 20, 1994

Revised version accepted: May 19, 1994 